\title{
PELATIHAN PEMBUATAN SABUN ANTISEPTIK BERBAHAN DASAR EMPON-EMPON DI KABUPATEN NGANJUK

\author{
Oleh:
}

Raya Sulistyowati ${ }^{1}$, Mirwa Adiprahara Anggarani², Erlix Rahmad Purnama ${ }^{3}$, Dimas Avian Maulana ${ }^{4}$, Tri Sudarwanto ${ }^{1}$, Ricky Eka Putra ${ }^{3}$

${ }^{1}$ Jurusan Pendidikan Ekonomi, Fakultas Ekonomi, Universitas Negeri Surabaya

11rayasulistyowati@unesa.ac.id

\begin{abstract}
Abstrak
Coronavirus 2019 (Covid-19) telah menjadi ancaman serius bagi semua masyarakat di setiap wilayah Indonesia bahkan di seluruh dunia. Setelah World Health Organization memutuskan bahwa Covid-19 menjadi pandemi global, berbagai peneliti berlomba-lomba menggali manfaat dari empon-empon untuk melawan Covid-19. Kandungan temulawak diyakini dapat mengatasi infeksi yang disebabkan Covid-19. Kabupaten Nganjuk merupakan salah satu daerah penghasil empon-empon. Namun, masyarakat Nganjuk masih memiliki pengetahuan yang kurang dalam mengolah empon-empon tersebut. Masyarakat sekitar masih sering mengalami gagal panen dalam penanaman empon-empon. Sehubungan dengan hal tersebut, pengenalan terhadap ilmu pengetahuan dan teknologi perlu dilakukan agar masyarakat Nganjuk mampu mengolah empon-empon tersebut menjadi suatu produk penangkal Covid-19. Dalam hal ini, empon-empon akan diolah menjadi sabun antiseptik yang bernilai ekonomis. Setelah berhasil memproduksi sabun tersebut, masyarakat Nganjuk juga dibekali dengan strategi pemasaran untuk memasarkan produk sabun antiseptik kepada pengguna.
\end{abstract}

Kata Kunci: ilmu pengetahuan dan teknologi, pemasaran, sabun antiseptik, empon-empon, covid-19

\section{Abstract}

Coronavirus 2019 (Covid-19) is a serious threat to every region in Indonesia and even throughout the world. After the World Health Organization decided that Covid-19 became a global pandemic, various researchers competed to explore the benefits of empons to fight Covid-19. The content of curcumin or curcuma can overcome Covid-19 infection. Nganjuk Regency is an empon-empon-producing region as a result of its agriculture. However, the citizen of Nganjuk is lackin of knowledge in processing empon-empon, it is regularly happened that the empon-empon harvested remain useless. Due to this case, we are introducing science and technology to educate the citizen of Nganjuk to be able to process these empon-empon into a product to prevent Covid-19. In this case, the empon-empon will be processed into an economically valuable antiseptic soap. After successfully producing the soap, the Nganjuk community was also equipped with a marketing strategy used to market the antiseptic soap product to users

Keywords: science and technology, marketing, antiseptic soap, empon-empon, covid-19

\section{PENDAHULUAN}

Coronavirus Disease 2019 atau yang sering dikenal dengan Covid-19 ini seakan menjadi monster yang menyeramkan bagi seluruh masyarakat di Indonesia bahkan di seluruh dunia. World Health Organization (WHO) sendiri telah menetapkan Covid-19 ini sebagai pandemi global sejak 9 Maret 2020 [1]. Oleh sebab itu, setiap negara perlu untuk menangani kasus Covid-19 ini lebih serius.

Penyebaran virus yang sangat cepat ini akhirnya juga menembus wilayah Indonesia. Indonesia yang memperoleh kasus pertama penderita Covid-19 sebelum WHO menyatakannya sebagai sebuah pandemi, yakni pada 2 Maret 2020. Mulai pada saat itu, perkembangan virus ini semakin cepat. Menurut harian Kompas, jumlah kasus Covid19 pada tanggal 14 April 2020 telah mencapai angka 4.839, dimana terdapat 3.954 pasien yang dirawat di Rumah Sakit, 459 meninggal, dan 426 sembuh. Menurut versi WHO (dalam Coronavirus disease 2019 (COVID-19) Situation Report - 83) pada dua hari sebelumnya (12 April 2020), Indonesia tercatat ke dalam urutan kedua tertinggi untuk jumlah kasus penderita Covid-19 terbanyak di wilayah Asia Selatan dan Tenggara. Hanya India, negara yang mengungguli Indonesia dalam hal tersebut.

Pada kondisi seperti ini, segala pihak di Indonesia mulai berperan aktif dalam mencegah laju persebaran Covid-19 sesuai dengan bidangnya masing-masing. Para 
dokter dan tenaga medis berada dalam garda depan dalam merawat pasien-pasien Covid19 di setiap Rumah Sakit Rujukan. Selain itu, para dokter dan tenaga medis tidak hentihentinya untuk mengingatkan kepada masyarakat akan pentingnya hidup bersih di tengah penyebaran Covid-19 ini.

Para ilmuwan di bidang kesehatan mulai mencari cara untuk mencegah dan menanggulangi virus ini untuk masuk ke tubuh manusia. Para guru besar juga berlomba untuk melakukan penelitian terhadap pencegahan Covid-19 ini untuk merusak tubuh manusia. Salah satu temuan dari Prof. Dr. drh. Chairul Anwar Nidom cukup mengesankan bagi masyarakat Indonesia. Profesor dari Universitas Airlangga ini mendaku bahwa rempah-rempah tradisional atau yang sering dikenal dengan kata emponempon itu mampu mencegah penularan Covid-19. Kandungan Curcumin atau Curcuma yang ada pada empon-empon tersebut diduga mampu mencegah dan mengurangi akibat dari infeksi Covid-19 [2]. Hal ini sangat disyukuri oleh masyarakat Indonesia yang mana negara Indonesia sangat dikenal akan rempah-rempah-nya. Hal ini pula dahulu yang menjadi daya tarik utama bagi negara lain untuk masuk dan menjajah Indonesia.

Pemerintah juga mulai memunculkan beberapa peraturan dan kebijakan untuk menghentikan laju penyebaran virus ini (Kepres Nomor 11 Tahun 2020, PP Nomor 21 Tahun 2020, dan lain-lain). Salah satu hasil dari peraturan itu adalah status keadaan darurat bencana wabah penyakit akibat Covid-19. Status ini memunculkan banyak kebijakan-kebijakan lain, salah satunya adalah kebijakan untuk tetap di rumah dan saling menjaga kebersihan badan dan lingkungan. Bahkan kebijakan terbaru yang muncul adalah Pembatasan Sosial Berskala Besar (PSBB) seperti yang tertuang pada PP Nomor 21 Tahun 2020.

Pemerintah daerah di setiap wilayah masing-masing juga turut menjalankan amanat dari pemerintah pusat untuk tetap menjaga kebersihan badan dan lingkungan serta mulai membatasi kegiatan untuk bersosialisasi di ruang lingkupnya. Selain itu, setiap pemerintah daerah juga memikirkan kelangsungan hidup bagi masyarakat-nya di kala pandemi wabah Covid-19 ini. Segala hasil alam yang ada di dalamnya mulai dikembangkan dan dijadikan suatu pegangan hidup bagi masyarakat di sekitarnya.
Salah satu kawasan yang cukup terkenal dengan hasil pertaniannya adalah Nganjuk. Kabupaten ini cukup terkenal sebagai penghasil empon-empon yang mana cukup bermanfaat dalam pencegahan penularan Covid-19. Namun, empon-empon tersebut masih digunakan selayaknya bumbu dapur dan bahan masakan yang lazim digunakan. Proses pengolahan lebih lanjut terhadap empon-empon menjadi suatu bahan penting dalam penanggulangan penyebaran Covid-19 ini perlu dikenalkan kepada masyarakat Nganjuk.

Kecamatan Sawahan merupakan salah satu penghasil empon-empon di Kabupaten Nganjuk. Serai merupakan salah satu emponempon yang dihasilkan di kecamatan Sawahan. Dalam satu sendok makan serai segar mengandung kurang lebih lima kalori yang berasal dari karbohidrat dan lemak menurut USDA. Kandungan mineral dalam serai adalah kalsium (3mg), kalium (34mg), mangan $(0,2 \mathrm{mg})$, magnesium $(2,9 \mathrm{mg})$ dan besi $(0,4)$. Kandungan lain dalam serai yang sering dimanfaatkan adalah minyak atsiri yang digunakan sebagai minyak esensial. Minyak atsiri sering dimanfaatkan sebagai penolak nyamuk sampai bahan antimikroba. Beberapa penelitian juga telah dilakukan untuk melihat aktivotas antimikroba serai [3] dan bahan terapi (obat) [4].

Melalui kegiatan Pengabdian Kepada Masyarakat Penugasan (PKMP) ini, masyarakat Nganjuk akan dikenalkan sebuah produk hasil olahan empon-empon tersebut. Empon-empon ini tidak diarahkan untuk dikonsumsi secara oral tetapi akan dibuat sebagai bahan dasar dari sabun antiseptik untuk menjaga kebersihan tubuh dan tangan pada khusunya. Hal ini juga akan mendukung gaya hidup masyarakat Indonesia untuk selalu hidup bersih. Selain itu, produk sabun antiseptik ini diharapkan menjadi alternatif bagi masyarakat dalam mencari hand sanitizer, aseptic gel, atau sabun cair yang lain.

Hasil pertanian di kabupaten Nganjuk menjadi meningkat dan bermanfaat di kala Covid-19 melanda. Hal ini juga diyakini akan meningkatkan taraf hidup dan pendapatan masyarakat Nganjuk khususnya para petani empon-empon yang ada di sana. Selain itu, warga Nganjuk juga akan dikenalkan cara produksi dan pemasaran dari sabun antiseptik dengan menggunakan IPTEK sehingga masyarakat Nganjuk dapat melakukan dua kegiatan ini dengan tetap berada di rumah. Melaui kegiatan ini, warga 
Nganjuk dapat memiliki mata pencaharian baru di kala suasana pandemi Covid-19 ini. Hal ini akan sangat mendukung perekonomian warga Nganjuk di tengah maraknya kegiatan PHK dan macetnya perekonomian di Indonesia.

\section{METODE}

Pelaksanaan PKMP tercantum dalam metodologi pelaksanaan yang tertera pada gambar 1.

Pada tahap pertama, kegiatan PKMP ini dimulai dengan penganalisisan situasi dan kondisi serta pendefinisian permasalahanpermasalahan yang ada pada masyarakat Nganjuk di tenah pandemi COVID-19. Pola hidup bersih dan pemanfaatan empon-empon yang merupakan hasil pertanian warga Nganjuk menjadi dua hal utama yang dijadikan dasar keberlangsungan PKMP ini. Kegiatan ini juga bertujuan untuk memantau kondisi mitra, berikut kesiapan mitra dalam serangkaian kegiatan PKMP ini. Selanjutnya, tim PKMP melakukan koordinasi untuk menyusun langkah-langkah dan strategi kegiatan PKMP.

Tahap kedua adalah pembuatan desain serta perancangan produk sabun antiseptik berbahan dasar empon-empon serta proses pemasarannya.

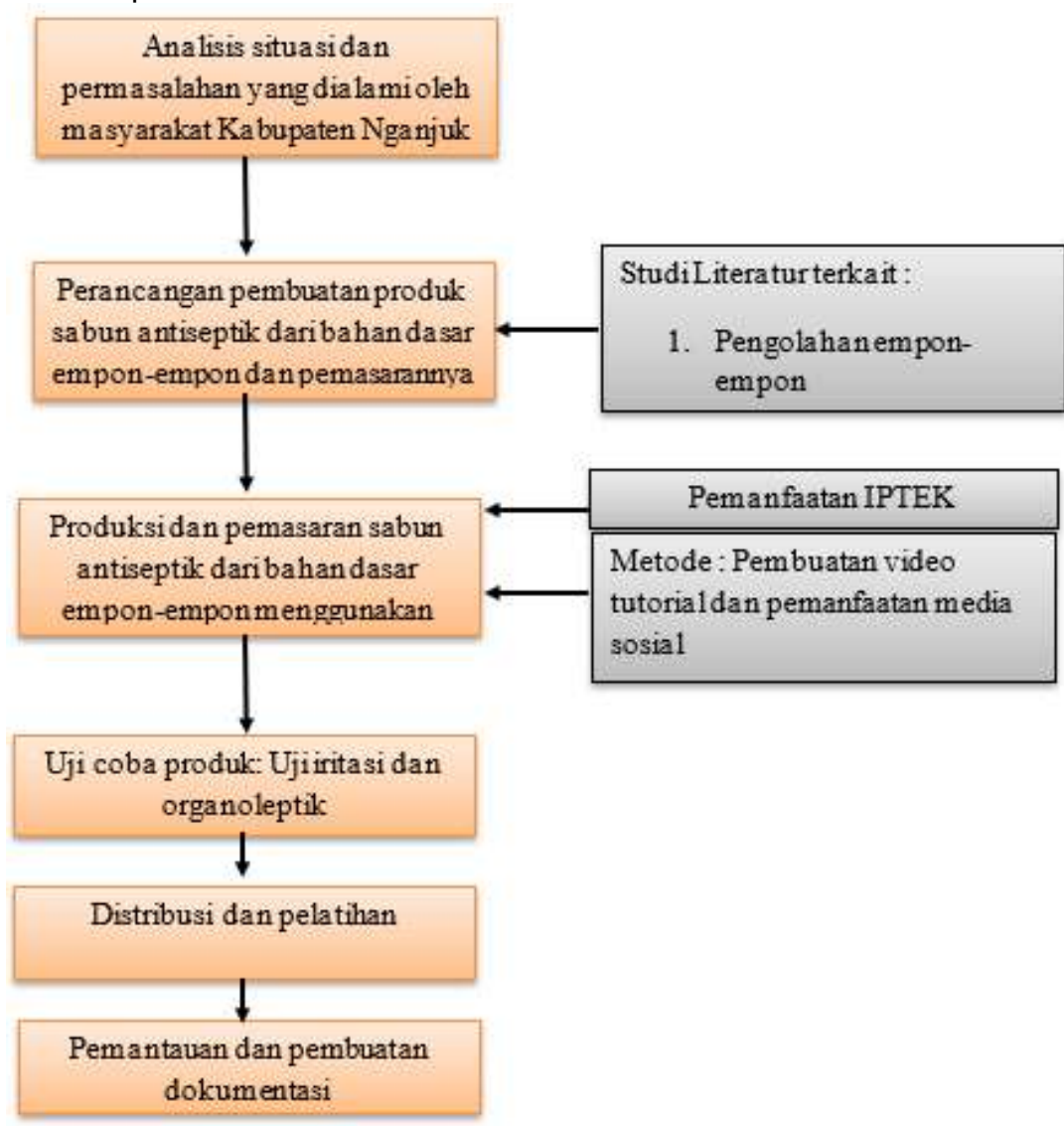

Gambar 1. Metode produksi dan pemasaran sabun antiseptik berbahan dasar empon-empon dengan menggunakan IPTEK

Dalam hal ini, kegiatan studi literatur mengenai pengolahan empon-empon dan pemasaran produk sabun antiseptik menjadi kegiatan utama untuk mendukung demi terciptanya prototipe produk sabun antiseptik dan model pemasarannya.

Setelah memperoleh rancangan atau bahkan sudah berbentuk sebuah prototipe, tim PKMP mulai melakukan implementasi terhadap pembuatan produk dan menerapkan strategi pemasarannya.Sabun antiseptik yang dibuat dalam PKMP ini adalah sabun padat. Pembuatan sabun diawali dengan mencampur asam stearat dengan virgin coconut oil dan olive oil dengan zat alkali $30 \%$ $(\mathrm{NaOH})$ yang dilakukan pada suhu $350 \mathrm{C}$. Pada proses penambahan zat alkali ini, adonan akan menjadi keras dan lengket, hal 
ini menunjukkan terjadinya pembentukan stok sabun. Kemudian, bahan tambahan yang lain seperti gliserin, sukrosa, cocamid-DEA, $\mathrm{NaCl}$, akuades, minyak atsiri serai ditambahkan ke dalam stok sabun. Setelah itu, adonan diaduk hingga terbentuk campuran yang homogen agar stok sabun menjadi sabun. Sabun kemudian dituangkan ke dalam cetakan dan dibiarkan selama kurang lebih 24 jam pada suhu ruang selama 3-4 minggu agar proses aging dapat dilakukan. Setelah itu akan dilakukan uji iritasi, uji organoleptik, dan uji mutu. Kegiatan produksi dan pemasaran ini dikenalkan ke masyarakat kabupaten Nganjuk, khususnya kecamatan Sawahan melalui tiga workshop dan pelatihan.

Kegiatan workshop pelatihan pertama bertemakan "Introduksi Iptek persyaratan mutu obat tradisional (Peraturan Kepala BPOM RI No. 12 Tahun 2014" dan “Introduksi TTG teknik penyiapan bahan dasar sereh untuk pembuatan sabun". Kedua kegiatan tersebut dilaksanakna secara daring dengan melibatkan masyarakat Nganjuk sebagai peserta PKMP. Tim PKMP secara langsung melakukan kegiatan penyiapan bahan dasar sereh sebagai bahan dasar sabun di lalu peserta mengamati melalui sambungan video call. Gambar 2 merupakan contoh bahan baku sereh sebagai bahan dasar sabun antiseptik.

Pada pelatihan ini ditentukan kriteria sereh yang dijadikan bahan dasar sabun. Tim PKMP menjelaskan ciri-ciri dan memberikan introduksi iptek mengenai preparasi sereh sebelum diolah menjadi bahan baku sabun. Sereh segar yang masuk kriteria dibersihkan dari kotoran dengan cara dicuci, lalu dikeringkan dan dijemur.

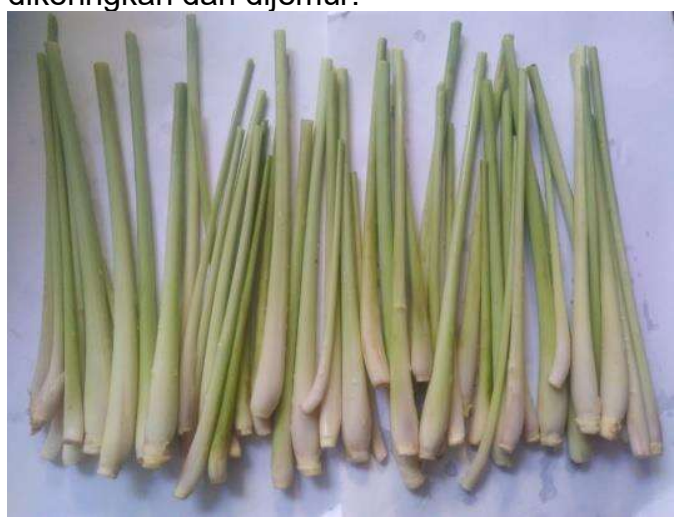

Gambar 2. Bahan baku sereh

Workshop dan pelatihan kedua mengusung tema "Introduksi Iptek mengenai khasiat sereh dan sabun antiseptik" dan "Introduksi TTG teknik pembuatan sabun antiseptik berbahan dasar sereh". Worskshop dan pelatihan ini menjelaskan cara-cara pembuatan sabun antiseptik berbahan dasar sereh dan manfaat serta khasiat dari sabun tersebut. Tim PKMP secara langsung melakukan pembuatan sabun antiseptik berbahan dasar sereh lalu peserta mengamati melalui sambungan video call. Peserta dapat melakukan tanya jawab dan diskusi sembari mengamati proses pembuatan sabun antiseptik. Gambar 3 sampai 5 menjelaskan proses ekstraksi sereh serta alat-alat yang diperlukan untuk membuat sabun sereh.

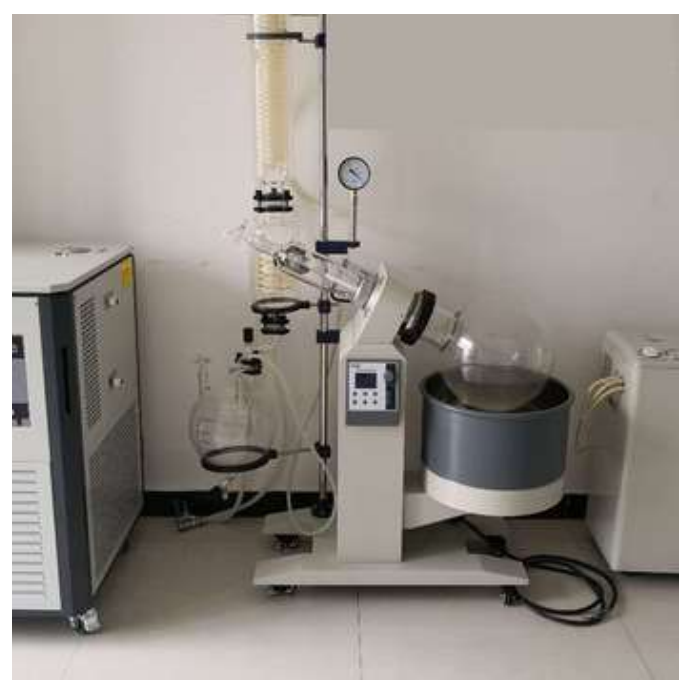

Gambar 3. Proses ekstraksi sereh

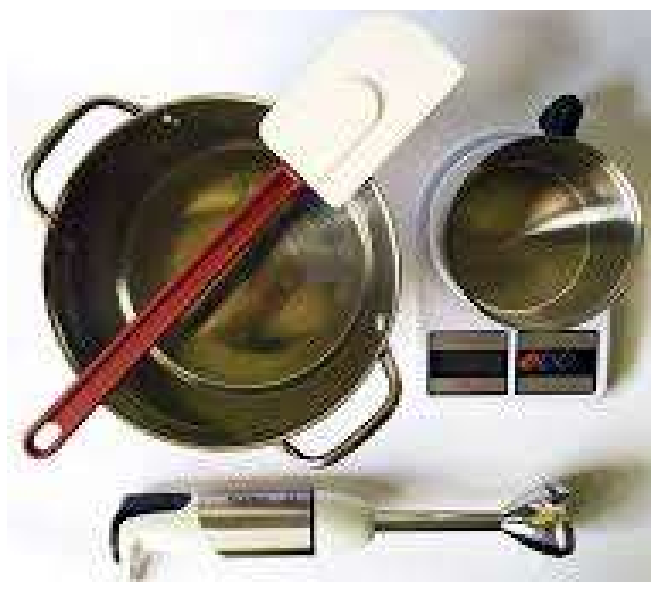

Gambar 4. Alat yang diperlukan dalam pembuatan sabun 


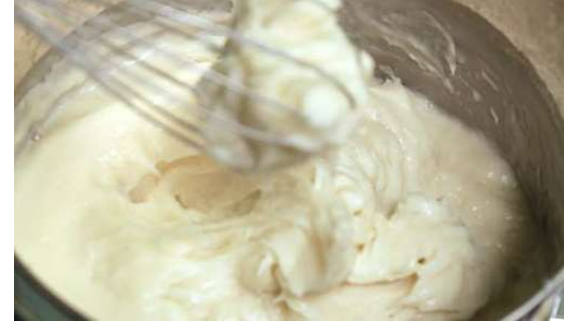

Gambar 5. Proses pembuatan sabun

Workshop dan pelatihan bagi warga Nganjuk ini bertujuan agar masyarakat kabupaten Nganjuk khusunya kecamatan Sawahan dapat memproduksi sabun antiseptik berdasarkan empon-empon hasil pertaniannya sendiri.

Untuk mengetahui kualitas sabun yang telah dibuat, tim akan melakukan uji kualitas sabun padat transparan yang siap dikemas sesuai dengan SNI-06-3532-1994. Kualitas yang akan diuji meliputi kadar air, jumlah asam lemak tersabunkan, asam lemak bebas/alkali bebas, asam lemak tak tersabunkan, dan minyak mineral. Untuk pengujian $\mathrm{pH}$ akan dilakukan sesuai dengan standar ASTM. Pengujian organoleptik dilakukan secara terbatas terhadap 25 panelis semi terlatih.

Dalam tahap ini, pemanfaatan IPTEK dilakukan untuk mengoptimalkan kegiatan produksi dan pemasaran tersebut. Berdasarkan latar belakang pendidikan tim PKMP dan pengalaman yang telah dimiliki, kegiatan ini diyakini dapat menghasilkan produk dan kegiatann pemasaran yang baik dan sesuai bagi masyarakat Nganjuk.

Pada tahap uji coba produk, tim PKMP ini melakukan uji coba terlebih dahulu terhadap produk sabun antiseptik berbahan dasar empon-empon dan memasarkannya pada area terbatas kampus Unesa. Hasil uji coba tersebut menjadi masukan-masukan untuk perbaikan proses produksi produk dan pemasaran produk tersebut.

Setelah melalui masa uji coba, produk sabun antiseptik dan model pemasarannya siap didistribusikan ke masyarakat Nganjuk.

Workshop dan pelatihan ketiga memiliki tema "Introduksi IPTEK untuk pengemasan sabun antiseptik" serta "Manajemen Bisnis dan Pemasaran". Workhsop dan pelatihan ini bertujuan untuk memberikan pengetahuan ke masyarakat Nganjuk mengenai teknik desain dan pengemasan serta pemasaran produk sabun antiseptik tersebut sehingga mereka dapat mengenalkan produk internal mereka ke wilayah sekitar Nganjuk. Workshop yang dilakukan juga secara daring ini mengenalkan pemanfaatan IPTEK yang tidak hanya pada kegiatan produksi tetapi juga dalam memasarkan produk dengan optimal.

Kegiatan akhir dari pelaksanaan PKMP ini adalah pemantauan dan pembuatan dokumentasi. Pada masa pemantauan ini, masyarakat Nganjuk dapat terus berinteraksi dengan tim PKMP untuk memperkaya pengetahuan dan pengalaman dalam proses produksi dan pemasaran produk berbasiskan IPTEK. Pemantauan ini dalam arti menjaga hubungan baik antara tim PKMP (Unesa) dengan masyarakat Kabupaten Nganjuk setelah kegiatan. Kerjasama ini juga dapat meningkatkan kegiatan kerjasama dua belah pihak khususnya dalam keberlanjutan program PKMP ini kelak. Selanjutnya pembuatan dokumentasi yang dapat dilakukan sebagai laporan tim PKMP kepada pihak kampus dan sebagai bahan dokumentasi kegiatan PKMP yang dapat digunakan oleh warga Nganjuk.

\section{HASIL DAN PEMBAHASAN}

Kegiatan PKMP ini dilaksanakan pada bulan April hingga Juni 2020 di Kecamatan Sawahan, Kabupaten Nganjuk. Kegiatan ini diawali dengan survey mengenai kondisi kesiapan mitra. Melalui survey ini, pemetaan terhadap gambaran umum dari jenis emponempon yang dikembangkan dan sereh merupakan salah satu jenis empon-empon yang kurang mendapat perhatian daripada jenis empon-empon yang lain.

Kegiatan selanjutnya adalah pengoordinasian langkah-langkah dan strategi kegiatan PKMP. Kegiatan ini menghasilkan tahapan-tahapan rinci dalam melaksanakan PKMP serta pembagian tugas personil. Masukan dari personil dan fakta di lapangan pada saat survey menjadi dasar dalam menentukan tahapan kegiatan beserta strategi.

Selanjutnya, kegiatan PKMP berlanjut ke workshop dan pelatihan pertama secara daring. Dua kegiatan ini berjalan lancar dan respon peserta sangat baik. Hasil dari kegiatan workshop dan pelatihan pertama ini cukup bagus. Peserta merasakan manfaat yang besar dari workshop dan pelatihan tahap pertama ini.

Kegiatan workshop dan pelatihan kedua menitikberatkan pada proses pembuatan dari sabun sereh tersebut serta manfaat dan 
khasiat dari sabun sereh. Warga kecamatan Sawahan, kabupaten Ngajuk terlihat antusias dalam mengikuti kelanjutan dari workshop dan pelatihan pertama tersebut.

Tahapan akhir dari rangkaian kegiatan PKMP ini adalah uji coba produk. Melalui uji coba ini, pengembangan proses produksi sabun sereh dan pemasaran dari sabun antiseptik tersebut dapat dilakukan menjadi lebih baik lagi.

Selanjutnya, masyarakat Nganjuk khususnya warga Sawahan juga dibekali skill dalam mendesain kemasan sabun serta strategi pemasaran sabun antiseptik tersebut.

Melalui kegiatan Pengabdian Kepada Masyarakat ini, masyarakat Nganjuk juga dikenalkan pentingnya pemanfaatan IPTEK dalam melakukan produksi dan memasarkan produk sabun antiseptik dengan bahan dasar empon-empon tersebut. Selanjutnya, warga Nganjuk memiliki sebuah profesi wirausaha baru dalam mengolah empon-empon hasil pertanian sendiri menjadi sebuah produk sabun antiseptik yakni sabun sereh yang sangat bermanfaat pada kondisi saat ini. Hal ini diyakini dapat meningkatkan perekonomian warga Nganjuk di tengah pandemi Covid-19 meskipun harus tetap berada di rumah.

\section{SIMPULAN DAN SARAN}

Pada bagian ini, terdapat dua subbagian, yaitu simpulan dan saran

\section{Simpulan}

Seluruh rangkaian kegiatan PKMP telah terlaksana dan memperoleh hasil yang memuaskan. Kegiatan workshop dan pelatihan telah diikuti oleh peserta dan mendapatkan respon yang baik. Dimana peserta mendapatkan skill memproduksi sabun antiseptik sereh dan dasar-dasar pemasaran yang dapat digunakan sebagai bekal dalam peluang usaha di bidang ini.
Saran

Rencana tindak lanjut dari PKMP ini adalah pemanfaatan Teknologi Informasi terhadap pemasaran tingkat lanjut terhadap produk sabun antiseptic sereh tersebut. Pemasaran digital tersebut diprediksi akan dapat meningkatkan omset dari penjualan sabun dengan menjaring para generasi milenial. Pemasaran digital ini juga diyakini dapat meningkatkan cakupan wilayah pemasaran dari penjualan produk sabun antiseptik sereh tersebut.

\section{DAFTAR PUSTAKA}

E. Nicastri. et al. 2020. National Institute for the Infectious Diseases "L. Spallanzani", IRCCS. Recommendations for COVID-19 Clinical Management. Infectious disease reports (Infect Dis Rep), PAGEpress.

L.A.Gonzalez-Paz. Et al. 2020. Theoretical Molecular Docking Study of the StructuralDisruption of the Viral 3CLProtease of COVID19 Induced by Binding of Capsaicin, Piperine and Curcumin Part 1: A Comparative Study with Chloroquine and Hydrochloroquine Two Antimalaric Drugs. Research Square.

R.B.A. Almeida. et al. 2013. Antimicrobial activity of the essential oil of Cymbopogon citratus (DC) Stapf. on Staphylococcus spp., Streptococcus mutans and Candida spp. Revista Brasileira de Plantas Medicinais, v.15(4), pp.474-482. https://doi.org/10.1590/S151605722013000400002

G.Shah. et al. 2011. Scientific basis for the therapeutic use of Cymbopogon citratus, stapf (Lemon grass). Journal of Advanced Pharmaceutical Technology \& Research, v.2(1), pp.3-8. https://doi.org/10.4103/2231-4040.79796 